\title{
Upravljanje znanja
}

Ste že kdaj imeli občutek, da je nekdo isto stvar opravil že pred vami, pa niste yedeli, kdo in kako ga najti, da bi ga vprašăli za način?

Ste že kdaj naključno srečali koga in od njega izvedeli ravno tisto informacijo, $k i$ ste jo potrebovali pri trenutnem delu?

Znanje je lahko shranjeno v človeškil glavah in gre za implicitno znanje ali pa je zapisano in je to eksplicitno znanje. Pri tem je pomembno zlasti slednje dejstvo in sicer, da je nemogoče v celoti zajeti in zapisati vse bogastvo, ki se skriva $v$ glavah. Eksplicitno znanje lahko hranimo in poiščmo, ko ga rabimo. Implicitno znanje pa izvabljamo iz ljudi z gojenjem kulture dialoga. Prav povezovanje med ljudmi in pogovori omogočajo prenašanja tistega, kar je zaklenjeno $v$ človeškilt glavah in je verjetno, da ne bo nikoli zapisano, vendar se pretaka med ljudmi takrat, ko si pripovedujejo zgodbe ali drug drugemu pomagajo po načelu mentorstva. $V$ tem duhu je pojem upravljanja znanja opredelil tudi Arian Ward iz Work Froniters International, ki pravi: "Ne gre za to, da bi ustvarili enciklopedijo, ki bi zajemala vse, kar je kdo kadarkoli vedel. Gre za to, da bi izsledili tiste, ki poznajo 'recept' ter negujejo kulturo in tehnologijo, ki jim omogoča, da spregovorijo."

Za pridobivanje znanja sta na voljo dve poti:

- lahko iščete tisto, kar vedo drugi, in poiščete ustrezne ljudi ter se z njimi pogovorite; ta pot vodi do mreže povezav in tvori prav učne skupnosti;

- lahko pa poiščete tisto, kar je že znano, eksplicitno zapisano, in lahko to s pridom uporabite za reševanje svojega problema.

Pri tem je treba opozoriti na eno slabost zajemanja in uporabe eksplicitnega znanja; vsi vemo, da znanje izredno hitro zastareva,
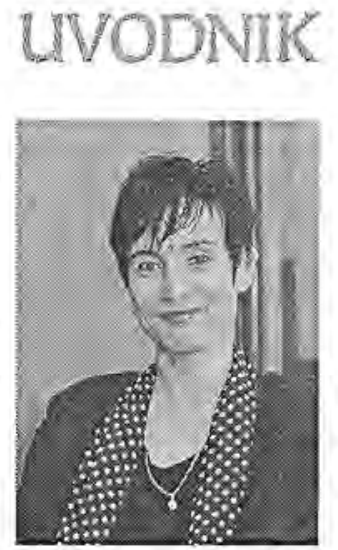

mag. Daniela Brečko prepolovna doba je 2 leti, in ga je torej treba osveževati. Nekateri strokovnjaki v povezavi z zastarevanjem znanja celo menijo, da noben pisni dokument ne vsebuje znanja, temveč zgolj podatke. Podatki pa sprožijo val misli, ki jih lahko primerjate s preteklimi izkušnjami, kar naj bi posledično vodilo $k$ razumevanju. Potemtakem je koristno znanje treba osveževati z organsko mrežo povezav med ljudmi, ki bodo znanje osvežili z novimi izkušnjami.

Upravljanje znanja postaja vse pomembnejša dejavnost učečih se organizacij, od podjetij do zavodov in društev. Postaja nova stroka: veliko organizacij zaposluje skrbnike znanja ali knowledge managerje, ki skrbijo za povezljivost in prenos znanja. Upravljanje znanja je hibridna stroka, ki ni niti umetnost niti znanost. Funkcionalno pokriva področje učenja in organizacijskega razvoja, človeških zmožnosti in tehnologije, ki omogoča prenos tega znanja. Prekrivanje teh treh področij lahko prikažemo s tremi krogi, upravljanje znanja pa je v njihovem presečišču. Presečišče tega modela nam hkrati ponuja udi odgovor na vprašanje, katere elemente je potrebno zagotoviti za uspešno prenašanje in upravljanje znanja:

- povezovanje ljudi, ki vedo, znajo vprašati in prisluhniti ter izmenjati izkušnje,

- skupno in zanesljivo informacijsko podporo oz. tehnologijo, ki omogoča izmenjavo znanja, ter

- nekatere procese, ki olajšujejo izmenjavo, potrjevanje in prečiščevanje ter selekcijo informacij.

Toda kako bomo vedeli, da pri upoštevanju ter vzpostavitvi tega modela v organizaciji ne bo šlo le za upravljanje podatkov, ko nam vendar gre za upravljanje znanja? Pogosto se izrazi s podatki, 
informacije in znanje zlivajo v neko zabrisano sliko. $V$ organizacijah govorimo o bazah podatkov, nekaj let kasneje o bazah znanja, ker je izraz pač postal všečnejši na trgu. Oxfordov slovar znanje opredeljuje kot "pozmavanje, ki si ga pridobimo z izkušnjami". Včasih potrebujemo svojo izkušnjo, da se česa naučino, věasih je dovolj, da kdo svojo izkušnjo podeli z nami. Ali boste ukrepali na podlagi tuje izkušnje, je odvisno od tega, kako dobro človeka poznate in koliko mu zaupate. In že se znajdemo na področju implicimega znanja. Toda znanje je še veliko več od tega. Znanje je namreč več kot zgolj vedeti kako - je tudi vedeti zakaj, vedeti kaj, vedeti $k d o$, vedeti kje in vedeti kdaj.

Vedeti kako ali strokonno znanje pomeni procese in postopke, tehnike in orodja, ki jih uporabljamo za to, da nekaj naredimo.

Vedeti zakaj se nanaša na strateške uvide, razumevanje konteksta naše vloge in vrednosti naših dejanj. Pomeni neko širšo sliko o stvareh.

Vedeti kaj so dejavnosti, ki so porrebne, da uspešno opravimo nalogo. Gre za podatke in informacije za odločanje ter stvari, ki jih moramo zbrati skupaj, da kaj izdelamo.

Vedeti kdo vključuje znanje o odnosih, stikih in mrežah povezav med ljudmi, ki jih lahko pokličemo "na pomoč". Gre za "poznam človeka, ki to ve".

Vedeti kje je tista nenavadna sposobnost nekaterih ljudi, $k i$ vedno najdejo prave informacije. Morda poznate koga, ki deluje kot pravi človeški iskalnik.

Vedeti kdaj pa je občutek za pravi trenutek, vedeti kdaj kaj storiti, kdaj lansirati izdelek na $1 \mathrm{rg}, \mathrm{kdaj}$ se odločiti ...

Upravljanje znanja vključuje vsa ta vedenja in prav zato je sam izraz tudi nekoliko protisloven. Očitki, ki se pri tem porajajo, so, da želino s procesom upravljanja znanja vršiti nadzor nad znanjem posameznikov. To pa vsekakor ni res, ker preprosto ni izvedljivo. To bi bilo podobno kot prizadevanje, da v sobi, polni mačk, želimo spraviti vse ven kot. Ne bo šlo najbolje. Če ne moremo spraviti mačk $v$ en kot, kako jih naj potem še prepričano, da bodo počele tisto, kar hočemo? Kdor pozna mačke, bi verjenno predlagal, da v sobo raje namestimo krožnike mleka, tople blazine, stebričke za praskanje nohtov ...-torej, da ustvarimo pravo okolje... In prav za to gre, ko govorimo o upravljanju znanja. Znanja nihče ne more upravljati $v$ pravem pomenu te besede, lahko pa upravljamo okolje, $v$ katerem ga je mogoče ustvarjati, odkrivati, zajemati, izmenjavati, prečiščevati, potrjevati, sprejemati, prilagajati, prenašati in uporabljati.

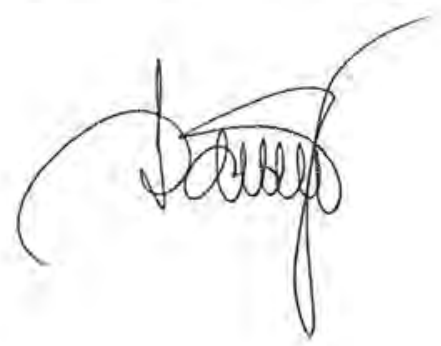

